JESTT Vol. 1 No. 9 September 2014

\title{
ZAKAT PRODUKTIF UNTUK MENINGKATKAN KINERJA PRODUKSI, MOTIVASI DAN RELIGIUSITAS \\ MUSTAHIQ \\ (STUDI KASUS PADA BAZ JATIM)
}

\begin{abstract}
Herwindo Ghora Nidityo
Mahasiswa Program Studi S1 Ekonomi Islam-Fakultas Ekonomi dan Bisnis-Universitas Airlangga Email : ghoranidityo@gmail.com
\end{abstract}

Nisful Laila

Departemen Ekonomi Syariah-Fakultas Ekonomi dan Bisnis-Unversitas Airlangga

Email : nisful.laila@gmail.com

\begin{abstract}
:
This research aims to determine the role of productive zakat toward the productive performance of mustahiq at their workplace.

This research used qualitative methods through descriptive case study analysis. Characteristic of theinformant research are the mustahiq that already registered as BAZ Jatim member. The number of informant tested of this research by six mustahiq and there are two managers of BAZNAS were asked for further information from the beginning of the research. The sampling technique used by this research is interview instrument and triangulatin process as the validity tool.

Based on the results of the research indicate that there are several role of productive zakat that affect the productive performance of mustahiq compared to the period before the zakat was distributed. The four factors as a result are the three main indicators, which is quantitative indicators, are change of number from the raw materials, quantity of productions, and the frequency of productions done. And the additional indicator is the effectivity of resource used, which is the factory overhead used of the production. Furthermore, in the process of research the productive zakat is also have a role to increase the motivation to produce and the religiosity of mustahiq.

Advice for the distributioninstitutions of zakat, are improves the number of productive programs and increases the management and distributions of the zakat, infaq, and shadaqah as a funding for the empowerment the people so that of the Ing term the zakat can be an instrument for the poor and slum reduction. For the second next research, are adding the informations of productive zakat and its management.
\end{abstract}

Keyword : productive zakat, performance, motivation, religiosity, mustahiq

\section{PENDAHULUAN}

Di negara-negara berkembang, kemiskinan merupakan permasalahan yang masih terjadi, termasuk di Indonesia. Data Badan Pusat Statistik tahun 2013 menunjukkan tercatat jumlah penduduk miskin di Indonesia sebesar 28,55 juta orang atau 11,47 persen dari jumlah seluruh penduduk Indonesia. Kemiskinan merupakan kondisi hidup yang serba
kekurangan.Qardhawi (dalam Miftah, 2008)menjelaskan, kemiskinan merupakan salah satu penyebab munculnya permasalahan ekonomi karena lemahnya sumber penghasilanlslam sebagai agama yang rahmatalilalamin telah memberikan solusi terhadap masalah kemiskinan, salah satunya dengan menggunakan instrumen zakat. Dalam surat Al Maidah ayat 55 dijelaskan perintah menunaikan zakat. 


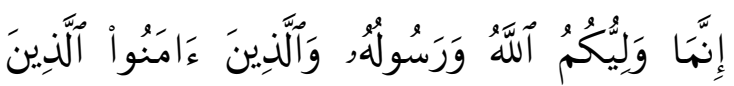

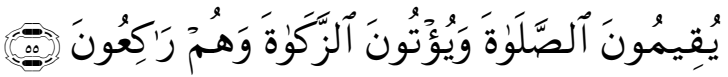
"innamã waliyyukumu allãhu waraslūhu wãlladzina ãmanū alladzina yuqīmūna alshshalãta wayu/tūna alzzakãta wahum rãki'ūna".

"Sesungguhnya penolong kamu hanyalah Allah, Rasul-Nya, dan orang-orang yang beriman, yang mendirikan shalat dan menunaikan zakat, seraya mereka tunduk (kepada Allah)."QS. Al Maidah(5):55 (Depag, 1993).

Zakat memiliki definisi akar kata yang mengacu pada makna aththaharah yang berarti bersih, al-nama' yang berarti pertumbuhan, dan al-zidayah yang berarti pertambahan. Menurut Suwiknyo (2009:279), zakat adalah harta yang dikeluarkan untuk mensucikan diri dari kotoran kikir dan dosa, dan menyuburkan harta atau memperbanyak pahala yang akan diperoleh bagi mereka yang mengeluarkannya. Zakat adalah keberkahan, penyucian, peningkatan dan suburnya perbuatan baik. Disebut zakat karena ia memberkahi kekayaan yang dizakatkan dan melindunginya. Zakat merupakan jumlah tertentu yang telah ditentukan oleh Allah SWT untuk mereka yang berhak terhadap zakat sebagaimana ditentukan dalam AlQuran.Zakat merupakan salah satu rukun Islam yang menjadi pilar pembangunan Islam.

Zakat sendiri dibedakan lagi menjadi dua jenis : zakat konsumtif dan zakat produktif. Zakat yang bersifat konsumtif adalah harta zakat secara langsung diperuntukkan bagi mereka yang tidak mampu dan sangat membutuhkan, terutama fakir miskin.Zakat konsumtif diberikan oleh mustahiq untuk menambah kemampuan konsumsinya yang sebelum zakat kurang untuk memenuhi kebutuhan dasarnya.Harta zakat diarahkan terutama untuk memenuhi kebutuhan pokok hidupnya, seperti kebutuhan makanan, pakaian dan tempat tinggal.Kebutuhan pokok yang bersifat primer ini terutama dirasakan oleh kelompok fakir, miskin, gharim, anak yatim piatu, yang tidak bisa berbuat banyak untuk mencari nafkah demi kelangsungan hidupnya.Sedangkan zakat produktif adalah zakat yang diberikan kepada mustahiq yang bersifat lebih kepada tata cara pengelolaan zakat yang akan diberikan kepada mustahiq, dari yang sebelumnya hanya menjadi pemenuhan kebutuhan saja lalu diubah penyaluran dana zakat yang telah dihimpun tersebut kepada hal-hal yang bersifat produktif dalam rangka pemberdayaan umat. Pengartian produktif dalam kata zakat produktif lebih berkonotasi kepada kata sifat. Kata sifat akan jelas maknanya apabila digabung dengan kata yang disifatinya. Dalam hal ini yang disifati adalah kata zakat, sehingga menjadi zakat produktif yang artinya zakat dimana dalam pendistribusiannya bersifat produktif lawan dari konsumtif (Asnaini, 2007) 
Sartika (2008) menjelaskan, zakat produktif adalah pendayagunaan zakat secara produktif yang pemahamannya lebih kepada bagaimana cara atau metode menyampaikan dana zakat kepada sasaran dalam pengertian yang lebih luas, sesuai dengan ruh dan tujuan syara'. Cara pemberian yang tepat guna, efektif manfaatnya dengan sistem yang serba guna dan produktif, sesuai dengan pesan syari'at dan peran serta fungsi sosial ekonomis dari zakat.Zakat produktif dengan demikian adalah pemberian zakat yang dapat membuat para penerimanya menghasilkan sesuatu secara terus menerus, dengan harta zakat yang telah diterimanya. Zakat produktif dengan demikian adalah zakat dimana harta atau dana zakat yang diberikan kepada para mustahiq tidak dihabiskan akan tetapi dikembangkan dan digunakan untuk membantu usaha mereka, sehingga dengan usaha tersebut mereka dapat memenuhi kebutuhan hidup secara terus-menerus.

$$
\text { Menurut Miftah (2008:426), }
$$
pembentukan modal yang diperoleh mustahiq dari dana zakat produktif tidak semata-mata dari pemanfaatan dan penembangan sumber daya alam, tetapi juga berasal dari sumbangan wajib para wajib zakat (muzakki) yang menyisihkan sebagian kecil harta kekayaannya. Disamping itu zakat produktif juga berperan penting dalam peningkatan sumber daya manusia dan penyediaan sarana dan prasarana produksi. Sehingga efek yag muncul ketika sumber daya manusia berkualitas dan sarana memadai adalah termanfaatkannya secara maksimal sumber daya alam yang akan berdampak pada mustahiq yaitu produktifitas tinggi, pendapatan riil tinggi, dan terpenuhinya kebutuhan modal untuk kelangsungan usaha mustahiq.Sartika (2008) menjelaskan, dengan berkembangnya usaha kecil menengah dengan modal yang berasal dari zakat akan menyerap tenaga kerja. Hal ini berarti akan mengurangi angka pengangguran, dengan berkurangnya angka pengangguran akan berdampak pada meningkatnya daya beli masyarakat terhadap suatu produk barang atau jasa. Meningkatnya daya beli masyarakat akan diikuti oleh pertumbuhan produksi, pertumbuhan sektor produksi inilah yang akan menjadi salah satu indikator adanya pertumbuhan ekonomi.

Di Indonesia, pada prakteknya, lebih banyak zakat yang disalurkan kepada mustahiq yang besifat konsumtif. Di mana zakat yang diberikan berupa vang tunai atau barang-barang sembako yang bersifat untuk menambah marginal prosperity to consume dari mustahiq. Hal ini menjadikan zakat konsumtif yang disalurkan hanya akan membuat mustahiq bertahan hidup dengan kebutuhan-kebutuhan pokoknya saja. Zakat konsumtif tidak akan mendorong mustahiq yang menerimanya untuk berusaha bekerja agar bisa keluar dari garis kemiskinan sehingga zakat konsumtif 
tidak efektif untuk mensejahterakan umat dalam jangka panjang.

Pemberian zakat dalam bentuk produktif lebih efektif dalam membantu mustahiq dari garis kemiskinan dan ketergantungan dari bantuan orang lain. Selain itu zakat produktif diharapkan mampu menstimulus mustahiq yang mendapatkan bantuan zakat untuk bekerja memenuhi kebutuhannya.Pemberian zakat produktif adalah pemberian zakat berupa modal kerja, barang-barang produksi, atau bantuan alat kerja yang bisa digunakan mustahiq yang menerimanya untuk meningkatkan produktifitas mustahiq. Dengan adanya bantuan modal berupa zakat produktif bagi kegiatan usaha mustahiq juga diharapkan akan mempunyai motivasi lebih kuat untuk memberikan kinerja yang baik dan menguntungkan, hal ini dikarenakan kesadaran individu mustahiq yang menyadari apabila bantuan yang mereka dapatkan dari orang lain yang sedang melakukan ibadah kepada Allah SWT. Oleh karena itu secara tidak langsung zakat produktif bisa menstimulus mustahiq untuk bekerja lebih giat dikarenakan adanya motivasi positif dari mustahia yang memiliki kesadaran membantu sesama muslim.

\section{LANDASAN TEORI}

\section{Ekonomi Islam}

PusatPengkajiandanPengembang an Ekonomi Islam (2007:43)mendefinisikan, tujuan utama ekonomi Islam yaitu falah atau kemuliaan.Falah dapat terwujud apabila terpenuhi kebutuhan-kebutuhan hidup manusia secara seimbang sehingga terciptalah mashlahah, yaitu segala bentuk keadaan baik material maupun non material yang mampu meningkatkan kedudukan manusia sebagai makhluk yang paling mulia. Mashlahah dasar bagi kehidupan manusia terdiri dari lima hal, yaitu agama (dien), jiwa (nafs), intelektual $(a q)$, keturunan (nash), dan material (maal).

Ekonomi Islam dibangun atas dasar perilaku individu yang rasional Islami.Rasional Islami adalah perilaku logis bagi individu yang sadar dan perhatian untuk memperoleh falah. Hal ini menuntun manusia untuk bervisi dan berprinsip jangka panjang. Dalam hal tertentu, manusia akan mengorbankan kepentingan duniawinya untuk mendapatkan kesejahteraan akhirat atau melakukan tindakan etis yang mengorbankan kepentingan individu atau material demi memperoleh mashlahah yang lebih besar. Perilaku etis dipandang sebagai perilaku rasional ketika sejalan dengan nilai-nilai falah (Pusat Pengkajian dan Pengembangan Ekonomi Islam, 2007:44).

Sistem ekonomi Islam merupakan sistem yang semua kegiatannya berlandaskan aturan-aturan yang telah diatur dalam Al Quran dan hadits, serta semua yang dikerjakan harus bertujuan untuk kemaslahatan umat manusia di dunia dan di akhirat pada nantinya.Karena pada dasarnya kegiatan 
ekonomi manusia dilarang hanya untuk mengejar keuntungan dunia saja tetapi juga harus memikirkan dampaknya di akhirat nanti.

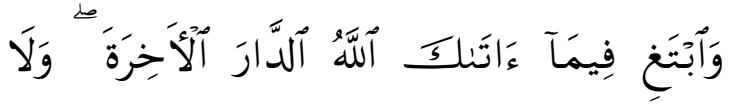

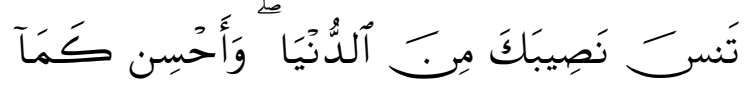

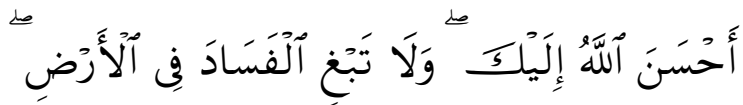

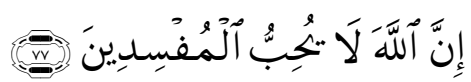
"waibtaghi fimā ātāka allāhu alddāra alākhirata walā tansa nashībaka mina alddunyā wa-ahsin kamā ahsana allāhu ilayka walā tabghi alfasāda fĩ al-ardhi inna allāha laa yuhibbu almufsidina".

"dan carilah pada apa yang telah dianugerahkan Allah kepadamu (kebahagiaan) negeri akhirat, dan janganlah kamu melupakan bahagianmu dari (kenikmatan) duniawi dan berbuat baiklah (kepada orang lain) sebagaimana Allah telah berbuat baik, kepadamu, dan janganlah kamu berbuat kerusakan di (muka) bumi. Sesungguhnya Allah tidak menyukai orang-orang yang berbuat kerusakan." Al Qashash:77 (Depag, 1993).

\section{Zakat}

Suwiknyo (2009:279) menjelaskan, zakat merupakan jumlah tertentu yang telah ditentukan oleh Allah SWT untuk mereka yang berhak terhadap zakat sebagaimana ditentukan dalam Al-Quran. Secara harfiah (etimologi) kata "zakat" berarti "tumbuh", "berkembang", "mensucikan", atau "membersihkan". Sedangkan secara istilah (terminologi) kata zakat merujuk pada aktivitas memberikan sebagian harta kekayaan dalam jumlah tertentu untuk diberikan kepada golongan tertentu. Zakat yang dikeluarkan akan mensucikan diri dari dosa, dan menyuburkan harta atau memperbanyak pahala orang yang mau mengeluarkan zakat tersebut.

Q.S. Al-Baqarah 110 :
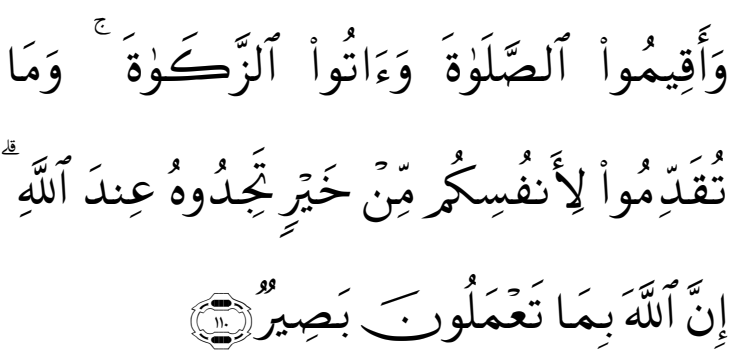

"wa-aqimu 'Iśśalāta wa ātuzzakāta wamā tuqaddimū li-anfusikum min khayrin tajiduhū 'indallāhi innallāha

bimāta'malūna basīirun".

"dan dirikanlah shalat dan tunaikanlah zakat. dan kebaikan apa saja yang kamu usahakan bagi dirimu, tentu kamu akan mendapat pahala nya pada sisi Allah. Sesungguhnya Alah Maha melihat apaapa yang kamu kerjakan."Al Baqarah:110 (Depag, 1993).

Menurut jenisnya, zakat terbagi atas dua macam :

1. Zakat Fitrah.

Adalah zakat yang wajib dikeluarkan muslim menjelang Idul Fitri pada bulan Ramadhan. Besar zakat ini setara dengan 2,5 kilogram makanan pokok yang ada di daerah bersangkutan. Sedangkan yang wajib dizakati adalah dirinya sendiri, dan orang-orang yang hidup di bawah tanggungannya (bila orang tersebut memiliki 
tanggungan).Syarat mengeluarkan zakat fitrah adalah Islam, memiliki kelebihan makanan untuk sehari bagi seluruh keluarganya, dan dilakukan pada waktu terbenamnya matahari di akhir bulan Ramadhan.

\section{Zakat Maal.}

Disebut juga zakat harta, mencakup hasil perniagaan, pertanian, pertambangan, hasil lauk, peternakan, hasil temuan, emas dan perak, serta hasil kerja (profesi) yang wajib dikeluarkan untuk membersihkan kekayaan dan menyucikan harta miliknya.Masing-masing memiliki perhitungannya sendirisendiri.Zakat mal diwajibkan oleh Allah bagi setiap muslim, bila kekayaan yang dimiliki memenuhi ketentuan dan syarat syara'.

\section{Zakat Produktif}

Zakat produktif adalah kegiatan pengelolaan dana zakat dengan cara pemberian bantuan yang diperuntukkan bagi kegiatan usaha produktif sehingga dapat memberikan dampak jangka panjang bagi para mustahiq, tidak hanya untuk sekali konsumsi saja. Salah satu contoh pendayagunaan zakat secara produktif dapat dilakukan dengan memberikan pembiayaan produktif (modal kerja) kepada mustahiq, memberikan pelatihan dan pendampingan kegiatan usaha, serta pemberian beasiswa-beasiswa kepada anak-anak pelajar.

Zakat produktif muncul setelah
dahulu dicontohkan oleh Nabi

Muhammad SAW. Melalui sunnah perbuatan beliau dapat dijadikan hujjah atau dasar bolehnya pengelolaan zakat secara produktif.Imran

(2009:37) menjelaskan, sebagaimana yang dicontohkan Rasulullah saat memberikan shadaqah sebanyak dua dirham kepada seorang fakir sambil memberikan anjuran agar mempergunakan uang tersebut masing-masing satu dirham untuk dimakan (dikonsumsi) dan satu dirham lagi untuk dibelikan kapak sebagai alat kerja, yang diharapkan dari kapak tersebut dapat bermanfaat untuk digunakan bekerja. Dari sunnah Rasulullah inilah dapat ditarik kesimpulan bahwa Rasulullah tidak serta merta memberikan shadaqah kepada fakir miskin, entah itu dihabiskan semua atau dipakai untuk keperluan lain, namun Rasulullah juga berpesan untuk membagi vang shadaqahnya tersebut untuk sebagian di konsumsi dan sebagian yang lain untuk dikelola sebagai modal kerja, dalam hal ini untuk dibelikan alat modal berupa kapak. Amirah menjelaskan, dasar untuk pelaksanaan zakat produktif adalah pada zaman Rasulullah yang dikemukakan dalam sebuah hadits riwayat Imam Muslim dari Salim Bin Abdillah Bin Umar dari ayahnya, bahwa Rasulullah telah memberikan kepadanya zakat lalu menyuruhnya untuk dikembangkan atau dizakatkan lagi. Dalam Al Quran surat Al-Hasyr (59) ayat 7 dijelaskan bahwa zakat adalah salah satu elemen pendistribusian kekayaan bagi sesama muslim: 


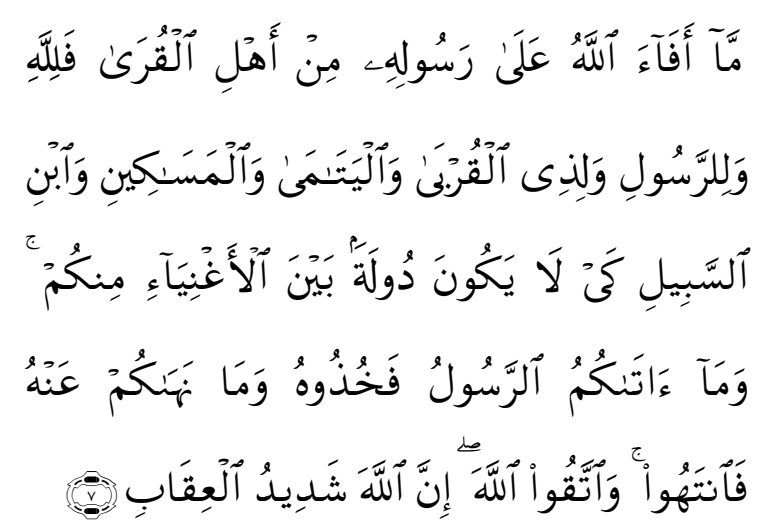

"mā afā-a allāhu 'alā rasuulihi min ahli alqurā falillāhi walilrrasūli walidzii alqurbā waalyatāmā wālmasākinni waibni alssabiili kay lā yakūna dūlatan bayna al-aghniyā-i minkum wamāātākumu alrrasūlu fakhudzūhu wamā nahākum 'anhu faintahuu waittaquu allāha inna allāha syadiidu al'iqābi".

"apa saja harta rampasan (fai-i) yang diberikan Allah kepada Rasul-Nya (dari harta benda) yang berasal dari penduduk kota-kota maka adalah untuk Allah, untuk Rasul, kaum kerabat, anak-anak yatim, orang-orang miskin dan orang-orang yang dalam perjalanan, supaya harta itu jangan beredar di antara orang-orang kaya saja di antara kamu. Apa yang diberikan Rasul kepadamu, maka terimalah. Dan apa yang dilarangnya bagimu, maka tinggalkanlah. Dan bertakwalah kepada Allah.Sesungguhnya Allah amat keras hukumannya."

Sartika (2008) mendefinisikan, pengembangan zakat bersifat produktif akan lebih optimal bila dilaksanakan Badan Amil Zakat atau Lembaga Amil Zakat karena sebagai organisasi yang terpercaya untuk pengalokasian, pendayagunaan, dan pendistribusian dana zakat kepada mustahiq. Dengan berkembangnya usaha kecil dan menengah yang modalnya berasal dari dana zakat produktif akan menyerap tenaga kerja, hal ini berarti secara jangka panjang angka pengangguran bisa dikurangi. Berkurangnya angka pengangguran akan berdampak pada meningkatnya daya beli masyarakat terhadap suatu produk barang atau jasa. Meningkatnya daya beli masyarakat akan diikuti oleh pertumbuhan produksi. Pertumbuhan produksi inilah yang akan menjadi salah satu indikator adanya pertumbuhan ekonomi.

\section{Zakat Produktif Sebagai Modal Usaha Mustahiq}

Menurut Antonio (2001:160), pembiayaan produktif adalah pembiayaan yang ditujukan untuk memenuhi kebutuhan produksi dalam arti luas, yaitu untuk peningkatan usaha, baik usaha produksi, perdagangan maupun investasi. Berdasarkan jenis keperluannya, pembiayaan produktif dibagi menjadi dua, yaitu :

1. Pembiayaan modal kerja, yaitu pembiayaan untuk memenuhi kebutuuhan peningkatan produksi secara kuantitatif (jumlah hasil produksi) dan kualitatif (peningkatan kualitas atau mutu hasil produksi) serta untuk keperluan perdagangan atau peningkatan utility of place dari suatu tempat.

2. Pembiayaan investasi, merupakan pembiayaan untuk memenuhi 
kebutuhan barang-barang modal (capital goods), serta fasilitas-fasilitas yang erat kaitannya dengan investasi.

Fadlillah (2012:38) menjelaskan, dalam setiap kegiatan ekonomi, dibutuhkan modal untuk dapat menjalankan dan mengembangkan usahanya.Modal dapat diartikan sebagai pengeluaran kegiatan usaha untuk membeli barang-barang modal dan perlengkapan produksi untuk menambah kemampuan memproduksi barang dan jasa untuk dikonsumsi oleh konsumen.Modal juga dapat diartikan pengeluaran sektor perusahaan untuk membeli atau memperoleh barangbarang modal yang lebih modern untuk menggantikan barang produksi lama yang sudah tidak dapat digunakan lagi.

Mubyarto (1985, dalam Fadlillah, 2012:39) menjelaskan, modal adalah sumber-sumber ekonomi diluar tenaga kerja yang dibuat oleh manusia. Modal dalam pengertian ekonomi adalah barang atau vang yang bersama faktor produksi lain seperti tanah dan tenaga kerja menghasilkan barang baru.

Nafi'ati (2012) dalam penelitiannya menjelaskan, zakat produktif dapat digunakan sebagai modal usaha mustahiq dengan cara pemberian bantuan vang tunai sebagai modal kerja usaha mikro dalam meningkatkan kapasitas dan mutu produksi usahanya. Selain itu pemberian dukungan kepada mitra binaan untuk berpenran serta dalam berbagai upaya untuk pemberdayaan usaha mikro, dan pembangunan industri untuk pemberdayaan yang ditujukan bagi mustahiq melalui program-program yang bertujuan untuk penciptaan lapangan kerja, peningkatan usaha, pelatihan, dan pembentukan organisasi (Pedoman unit pengelola zakat dan unit usaha jasa kevangan syariah, 2011:33).

\section{Kinerja}

Menurut Nawawi (2010:220), secara konseptual kinerja pada dasarnya dapat dilihat dari dua segi, yaitu kinerja pegawai secara individu dan kinerja organisasi. Kinerja pegawai adalah hasil kerja perseorangan dalam organisasi.Sedangkan kinerja organisasi adalah totalitas hasil kerja yang telah dicapai oleh suatu organisasi.Kinerja pegawai pegawai dan kinerja organisasi mempunyai keterkaitan yang erat.Tercapainya tujuan organisasi tidak bisa dilepaskan dari sumber daya yang dimiliki oleh perusahaan yang dipergunakan atau dijalankan oleh pegawai yang berperan aktif sebagai pelaku dalam upaya mencapai tujuan organisasi tersebut.

Nawawi (2010:222) menjelaskan, kinerja adalah fungsi hasil-hasil pekerjaan atau kegiatan yang ada dalam perusahaan yang dipengaruhi oleh faktorfaktor intern dan ekstern organsasi dalam mencapai tujuan yang ditetapkan selama periode waktu tertentu.

Menurut Wirawan (2009:5), konsep kinerja merupakan singkatan dari kinetika kerja yang dalam bahasa Inggris 
diterjemahkan sebagai performance. Kinerja adalah keluaran yang dihasilkan oleh fungsi-fungsi atau indikator-indikator suatu pekerjaan atau suatu profesi dalam waktu tertentu.

\section{Indikator Kinerja}

Wirawan (2009:69) menjelaskan, dalam mengukur kinerja, terdapat kriteria atau ukuran.Setiap indikator kinerja diukur berdasarkan kriteria standar tertentu. Kriteria tersebut adalah:

1. Kuantitatif (seberapa banyak).

Ukuran kuantitatif merupakan ukuran paling mudah untuk disusun dan diukurnya, yaitu hanya dengan menghitung seberapa banyak unit keluaran kinerja harus dicapai dalam kurun waktu tertentu.

2. Kualitatif (seberapa baik).

Ukuran ini melukiskan seberapa baik atau seberapa lengkap hasil harus dicapai. Kriteria ini antara lain mengemukakan akurasi, presisi, kemanfaatan, dan efektifitas. Standar kualitas dapat diekspresikan sebagai tingkat kesalahan seperti jumlah atau persentase kesalahan yang diperbolehkan per unit hasil kerja.

3. Ketepatan waktu pelaksanaan tugas.

$$
\text { Kriteria yang menentukan }
$$

keterbatasan waktu untuk memproduksi suatu produk, membuat sesuatu atau melayani sesuatu.
4. Efektivitas penggunaan sumber organisasi.

Efektivitas penggunaan sumber dijadikan indikator jika untuk mengerjakan suatu pekerjaan diisyaratkan menggunakan jumlah sumber daya tertentu seperti vang dan bahan baku.

5. Cara melakukan pekerjaan.

Kriteria ini digunakan sebagai standar kinerja jika kontak personal, sikap personal, atau perilaku karyawan merupakan faktor penentu keberhasilan melaksanakan pekerjaan.

6. Efek atas suatu upaya.

Pengukuran yang diekspresikan akibat akhir yang diharapkan akan diperoleh dengan bekerja. Standar jenis ini menggunakan kata-kata "sehingga" dan "agar supaya" yang digunakan jika hasilnya tidak dapat dikualifikasikan.

7. Metode melaksanakan tugas.

Standar yang digunakan jika ada undang-undang, kebijakan, prosedur, standar, metode, dan peraturan untuk menyelesaikan tugas.

8. Standar sejarah.

Standar yang menyatakan hubungan antara standar masa lalu dengan standar sekarang.Standar masa sekarang dinyatakan lebih tinggi atau lebih rendah daripada standar masa lalu dalam pengertian kuantitas dan kualitas.

9. Standar nol atau absolut.

Standar yang menyatakan tidak akan terjadi sesuatu. Standar ini dipakai jika tidak ada alternatif lain.

\section{Proposisi}

Penelitian ini meneliti bagaimanakah peranan zakat produktif dalam meningkatkan kinerja produksi, motivasi dan religiusitas mustahiq,sehingga 
akan menggunakan indikator-indikator kinerja dalam proses pengumpulan dan intepretasi datanya. Apabila dana zakat produktif mempunyai peran pada kinerja usaha milik mustahiq yang mendapat bantuan zakat produktif dari BAZ Jawa Timur, maka dana zakat produktif tersebut telah meningkatkan kinerja mustahiq.

\section{METODE PENELITIAN}

\section{Pendekatan Penelitian}

Metode

penelitian

kualitatifdinamakan sebagai metode penelitian baru, atau metode postpositivistik karena berlandaskan pada filsafat postpositivisme. Metode penelitian kualitatif bersifat seni (kurang terpola) dan disebut sebagai metode interpretive karena data hasil penelitian lebih berkenaan dengan interpretasi terhadap data yang ditemukan di lapangan.Sugiyono (2012:7)

Penelitian ini dilaksanakan untuk menjawab rumusan masalah: "bagaimana peranan dana zakat produktif terhadap kinerja produksi, motivasi dan religiusitas mustahiq?".Jawaban dari rumusan masalah tersebut tidak dapat diperoleh menggunakan perhitungan data kuantitatif, sehingga untuk memperoleh jawaban tersebut digunakan penelitian kualitatif. Pendekatan kualitatif adalah pendekatan penelitian yang berlandaskan pada filsafat postpositivisme, digunakan untuk meneliti pada kondisi objek yang alamiah dimana peneliti adalah sebagai instrumen kunci, teknik pengumpulan data dilakukan secara triangulasi (gabungan), analisis data bersifat induktif atau kualitatif, dan hasil penelitian lebih menekankan makna dari generalisasi (Sugiyono, 2012:9).

\section{Ruang Lingkup Penelitian}

Ruang lingkup penelitian terbatas pada sampel kelompok mustahiq program penyertaan modal bergulir BAZ Jatim dimana sebelumnya pihak BAZ sudah menyeleksi mustahiq-mustahiq yang layak untuk diberi pembiayaan dana zakat produktif sebagai modal usahanya. Informan kelompok mustahiq tersebut akan diwawancara oleh peneliti menggunakan ukuran indikator yang telah ditentukan, sehingga dapat dicari sampel tersebut untuk diteliti lebih dalam untuk mengetahui peranan zakat produktif dalam meningkatkan kinerja produksi, motivasi dan religiusitas mustahiq.

\section{Jenis dan Sumber Data}

Jenis data yang dibutuhkan dalam penelitian ini adalah berupa data primer karena bermaksud menggali informasi secara luas dan mendalam pada objek penellitian dengan melakukan wawancara satu persatu dengan pihak pengajar pondok pesantren. Penelitian ini menggunakan teknik purposive sampling dalam mendapatkan informan. Menurut Sugiyono (2012:218) purposive sampling adalah teknik pengambilan sampel sumber data dengan pertimbangan tertentu. 


\section{TeknikKeabsahan Data}

Penilaian keabsahan penelitian kualitatif terjadi pada waktu proses pengumpulan data. Untuk menentukan keabsahan data diperlukan teknik pemeriksaan atau instrumen pemeriksaan.Pelaksanaan teknik pemeriksaan didasarkan pada sejumlah kriteria-kriteria tertentu.Untuk memeriksa keabsahan data yang diperoleh maka penulis menggunakan teknik triangulasi data.Dalam penelitian ini, teknik pemeriksaan yang dipakai adalah teknik triangulasi sumber.Data yang telah di analisis oleh peneliti sehingga menghasilkan suatu kesimpulan, selanjutnya dimintakan kesepakatan dengan ketiga sumber data tersebut.

\section{Teknik Analisis Data}

Teknik analisis penelitian ini adalah pendekatan analisis kualitatif deskriptif. Analisis tersebut bertujuan menganalisis data studi kasus dengan membuat penjelasan (naratif) dan menggambarkan (deskripsi) kasus yang bersangkutan dan membuktikan proposisi teoritis yang telah dibuat.

\section{HASIL ANALISIS DAN PEMBAHASAN}

Dalam praktiknya, kinerja mustahiq penerima zakat produktif yang disalurkan oleh BAZNAS Jatim dalam kegiatan produksinya bergantung kepada pengelolaan masing-masing mustahiq penerima dan bergantung kepada BAZNAS Jatim dalam mengontrol kegiatan mustahiqnya. Nawawi (2010:222) menjelaskan, kinerja adalah fungsi hasil- hasil pekerjaan atau kegiatan yang ada dalam perusahaan yang dipengaruhi oleh faktor-faktor intern dan ekstern organsasi dalam mencapai tujuan yang ditetapkan selama periode waktu tertentu. Dalam kegiatan produksinya, para mustahiq dari BAZNAS Jatim menyatakan mereka sangat terbantu oleh penyaluran zakat produktif oleh BAZNAS Jatim, hal ini selain karena nominalnya cukup besar untuk usaha yang bersifat mikro, juga karena program modal usaha produktif milik BAZNAS ini merupakan program berkesinambungan, yakni berjalan dari tahun ke tahun. Seluruh mustahiq yang diberi bantuan zakat produktif terus dipantau oleh petugas BAZNAS tiap periode, apakah usahanya berkembang atau tidak, apakah pembayaran angsurannya lancar atau tidak, dan sebagainya. Sehingga mustahiq akan terpacu untuk meningkatkan perkembangan usahanya.

Berdasarkan indikator-indikator kinerja yang dimasukkan dalam proses wawancara, peningkatan kinerja produksi mustahiq dilihat dari indikator utama, yaitu indikator kuantitatif, adalah perubahan jumlah kuantitas bahan baku, kuantitas output produksi yang dihasilkan, dan frekuensi produksi yang dilakukan. Lalu juga dari indikator tambahan seperti efektivitas sumber daya yang digunakan yaitu pengeluaran tambahan produksi (Factory Overhead). Berdasarkan wawancara yang telah dilakukan, dalam praktik usahanya mustahiq menyatakan bahwa bantuan modal zakat produktif 
dari BAZNAS Jatim telah meningkatkan kemampuan produksi mereka dari sebelumnya, karena kemampuan membeli bahan baku mereka meningkat dari sebelumnya. Akibat dari peningkatan bahan baku yang dapat dijual, akhirnya akan meningkatkan proses produksi, yang pada akhirnya akan meningkatkan output produksi yang dihasilkan.

\section{Validitas Data}

Validitas data dapat dilakukan dengan beberapa cara untuk memperoleh keabsahan data, salah satunya dengan menggunakan triangulasi. Penelitian ini menggunakan metode triangulasi data untuk mengecek data yang diperoleh dari informaninforman yang telah diwawancarai mengenai peranan zakat produktif terhadap kinerja produksi mereka.Sugiyono (2012:274) menjelaskan, triangulasi sumber dilakukan ke tiga subjek yang berbeda, data dari sumber yang berbeda tersebut lalu dideskripsikan, dikategorikan, dan dianalisis oleh peneliti sehingga menghasilkan suatu kesimpulan yang selanjutnya dimintakan kesepakatan (member check) dengan masing-masing sumber tersebut. Dalam penelitian ini, triangulasi akan dilakukan kepada tiga sumber yang berbeda, yaitu informan, kelvarga informan, dan petugas BAZ Jatim yang berkepentingan memberikan bantuan dana.

\section{Keterbatasan Penelitian}

$\begin{array}{ccc} & \text { Penelitian ini dilakukan di Badan } \\ \text { Amil } & \text { Zakat } & \text { Provinsi Jawa }\end{array}$

Timur.Keterbatasan dari studi ini adalah terbatasnya data informan yang diberikan oleh BAZNAS Jatim.Fokus wawancara dalam penelitian ini hanya sebatas pendapat dari para informan mengenai peranan zakat produktif terhadap kinerja produksi mereka sebagai pengusaha mikro, sehingga tidak dapat mengetahui lebih jauh mengenai peranan zakat produktif dengan kegiatan olah data.

\section{SIMPULAN}

Berdasarkan hasil pembahasan pada bab empat, maka simpulan dari penelitian ini adalah

1. Zakat produktif yang disalurkan oleh BAZNAS Jatim memiliki peranan dalam meningkatkan kinerja produksi mustahiq, dikarenakan zakat produktif yang disalurkan dalam bentuk modal usaha kepada mustahia dapat meningkatkan indikator-indikator kinerja yang telah ditentukan. Indikator utama, yaitu indikator kuantitatif, adalah perubahan jumlah kuantitas bahan baku, kuantitas output produksi yang dihasilkan, dan frekuensi produksi yang dilakukan. Lalu juga dari indikator tambahan seperti efektivitas sumber daya yang digunakan yaitu pengeluaran tambahan produksi (Factory Overhead).

2. Selain mendapatkan hasil peningkatan indikator kinerja produksi, dalam penelitian juga didapatkan hasil lain yaitu perubahan dari aspek rohani mustahiq, yaitu peningkatan motivasi dalam berproduksi dan religiusitas 
mustahiq setelah mendapatkan penyaluran zakat produktif. Hal ini dikarenakan BAZNAS Jatim melaksanakan kegiatan-kegiatan yang bersifat spiritual selain penyaluran materi berupa zakat produktif sehingga para mustahiq tidak hanya mendapat bantuan dana saja tetapi juga terdapat bantuan moral dan rohani seperti mendapatkan kesempatan untuk studi banding, kegiatan pengajian, istighasah, serta perkumpulan rutin antar anggota, kegiatan tanya jawab dalam mengatasi masalah usaha tidak berkembang.

\section{DAFTAR PUSTAKA}

Al Qur'an dan Hadits.

Antonio, Muhammad Syafi'i. 2001. Bank Syariah: Dari Teori Ke Praktik. Jakarta: Gema Insani.

Asnaini.2007. Zakat Produktif Dalam Perspektif Hukum Islam. Yogyakarta: Pustaka Belajar.

Fadlillah, Diah Nur. 2012. Analisis Penyerapan Tenaga Kerja Pada Industri Kecil (Studi Kasus di Sentra Industri Kecil Ikan Asin di Kota Tegal).Skripsi tidak diterbitkan. Semarang FEB Universitas Diponegoro.

Miftah.2008, Pembaharuan Zakat Untuk Pengentasan Kemiskinan di Indonesia.Innovatio, Vol. VII, No. 14, Juli-Desember 2008.

Nafi'ati, 2012.Pemberdayaan Mustahik Melalui Pendayagunaan Zakat
Produktif (Studi Kasus Baitul Maal Hudatama Peduli Semarang Tahun 2011). Skripsi tidak diterbitkan. Sleman FE Universitas IAIN Walisongo.

Nawawi, Ismail. 2010. Budaya Organisasi Kepemimpinan dan Kinerja Organisasi. Sidoarjo: Mitra Media Nusantara.

Pusat Pengkajian dan Pengembangan Ekonomi Islam. 2007. Ekonomi Islam. Edisi Kesatu. Jakarta: PT Raja Grafindo Persada.

Sartika, Mila. 2008. Pengaruh Pendayagunaan Zakat Produktif Terhadap Pemberdayaan Mustahiq pada LAZ Yayasan Solo Peduli Surakarta. Vol. II, No. 1, Juli 2008.

Sugiyono. 2012. Metode Penelitian Kuantitatif, Kualitatif, dan R\&D. Bandung: Alfabeta.

Suwiknyo, Dwi. 2009. Kamus Lengkap Ekonomi Islam. Yogyakarta: Total Media.

Wirawan. 2009. Evaluasi Kinerja Sumber Daya Manusia: Teori Aplikasi dan Penelitian. Jakarta: Salemba Empat. 